\title{
Svijet Biblije - neophodan kontekst kod proučavanja Starog zavjeta
}

\author{
Monika Bajić \\ Biblijski institut, Zagreb \\ mbajic@bizg.hr
}

UDK: 27-242:261

Pregledni znanstveni rad https://doi.org/10.32862/k1.15.2.1

\section{Sažetak}

Biblija izvorno nije napisana za suvremenog čitatelja, ali svjedočanstvo Crkve je da i danas nastavlja čitateljima/slušateljima govoriti Božju riječ. Međutim, mnogi suvremeni čitatelji Biblije nailaze na tekstove koji trebaju daljnja objašnjenja jer biblijski autori nisu ponudili pojašnjenje svojih rukopisa. Pretpostavljali su da su čitatelji njihova vremena bili upoznati s okruženjem i da su mogli razumjeti napisane događaje bez daljnjeg pojašnjenja. Da bismo postigli „legitimnu“ interpretaciju starozavjetnih tekstova, prvo moramo pravilno razumjeti Sveto pismo, što znači da se biblijski tekst mora čitati u njegovu užem i širem kontekstu. Tek unutar konteksta postaje jasno što je autor htio reći. Glavni argument ovog rada pokazat će kako se Biblija može cjelovitije razumjeti samo uz pozadinu drevnoga Bliskog istoka (u daljnjem tekstu DBI). Širi kontekst sastoji se od znanja okolnih naroda tijekom biblijskih vremena ( $t$. hebrejske Biblije). Ispitivanjem i konzultiranjem drevnih bliskoistočnih tekstova i arheoloških nalaza, postižemo cjelovitije i bogatije razumijevanje odredenoga biblijskog teksta ili odlomka. Ovaj članak prikazuje kroz nekoliko konkretnih primjera kako arheološki nalazi, natpisi i drevni bliskoistočni tekstovi mogu pomoći u razumijevanju šireg konteksta starozavjetnog svijeta. Zauzvrat, širi kontekst biblijskog svijeta može prosvijetliti i/ili razjasniti težak, nerazumljiv ili dvosmislen biblijski tekst i tada tumačenje svetopisamskih spisa postaje točnije i bliže izvornoj poruci i značenju. 
Ključne riječi: Stari zavjet, tumačenje, starozavjetni tekstovi, drevni Bliski istok, drevni bliskoistočni tekstovi, arheologija, arheološki nalazi i natpisi, interpretacija, biblijski tekst, kontekst, drevni svjetonazor, okolni narodi

\section{Uvod}

Prosječni suvremeni kršćanin čini se nije toliko vješt u kvalitetnom proučavanju i čitanju Biblije s razumijevanju ili jednostavno rečeno - biblijska je pismenost drastično pala u većini današnjih crkava.1 Jedan od problema koji neizbježno proizlazi iz toga jest da su „[d]revni dokumenti poput Biblije, često podložni neupućenom tumačenju temeljenom na modernim zabludama ili pristranostima. Osobna i doktrinarna tumačenja također mogu ponešto izmijeniti značenje teksta ili uskladiti priče kako bi se uklonile nedosljednosti ili proturječja " (Matthews i Moyers 2012, 26-27). Biblijska pismenost ne znači samo čitanje Biblije. To znači moći razumjeti (izvorno značenje) i ovladati uporabom novo shvaćene biblijske poruke u svakodnevnom životu. Zapravo, znači ići korak dalje od biblijskog znanja prema biblijskoj pismenosti. To nije samo poznavanje sadržaja već i stjecanje spoznaja o smislu u veličanstvenoj istini Svetog pisma - ne samo zbog nas samih nego radi naših crkava.

Moramo biti svjesni da smo vremenski i prostorno odmaknuti iz biblijskog svijeta pa ne možemo ispravno shvatiti punoću i iskonski značaj teksta. Problematika postaje očita kada prosječni suvremeni čitatelj Biblije i ozbiljan student naiđe na odlomke koji prikazuju određene društvene ili kulturne običaje, zakone, vjerske prakse i vjerovanja te zemljopisne lokacije koje su mu nepoznate. Walton (2017, pogl. 1) nam daje srž problema s kojim se susreću suvremeni čitatelji Biblije: „Autori Svetog pisma djeluju u sferi višeg konteksta. Sa svojom publikom dijele svjetonazor, povijest i niz iskustava te mogu pretpostaviti mnogo zajedničkog jezika. No, kada dolazimo do Starog zavjeta kao čitatelji, ulazimo u publiku nižeg konteksta, čak i kad pokušavamo protumačiti komunikaciju višeg konteksta. Tako teološka bit Starog zavjeta nije samo ugrađena u književnost, ugrađena je

1 Pogledajte neke članke o biblijskoj nepismenosti: "The Bible and Spirituality: the Decline in Biblical Literacy among Evangelicals and the Future of the Quiet Time." (https://biblicalstudies. org.uk/pdf/anvil/19-2 099.pdf? cf chl managed tk =pmd qyNr8Wnjr9L7fmTO7xaGA. YDgcUmbGhcTRfDA1nN MM-1631104258-0-gqNtZGzNAtCjcnBszQil); "Biblical Illiteracy in US at Crisis Point, Says Bible Expert." (https://www.christianpost.com/news/biblicalilliteracy-in-us-at-crisis-point-says-bible-expert.html); „Biblical illiteracy is 'biggest problem' facing global evangelicalism.” (https://www.ecumenicalnews.com/article/biblicalilliteracy-utmost-problem-facing-global-evangelicalism/60809.htm); "Biblical illiteracy is a big problem-for Christians." https://www.patheos.com/blogs/jaysondbradley/2019/02/bibleliteracy/\#disqus thread; "Discipling in an Age of Biblical Illiteracy." (https://lifewayresearch. com/2017/07/10/discipling-in-an-age-of-biblical-illiteracy/). 
u kulturu“. ${ }^{2}$ Bez dublje analize dodatnih podataka o okolnim narodima, njihovoj kulturi i religijama, uvijek ćemo biti lišeni preciznijeg i boljeg razumijevanja, a time i korektnije interpretacije Svetog pisma.

Svrha je ovog članka pozabaviti se značajem poimanja drevnih bliskoistočnih kultura u potrazi za rekonstrukcijom miljea starozavjetnog svijeta za bolje iliti obaviješteno biblijsko čitanje i tumačenje (u daljnjem tekstu osobna teologija). Rezultat toga je uspješniji kršćanski život temeljen na bogatijem i dubljem razumijevanju božanske priče i nauka Biblije te kako su oni međusobno povezani. Postižemo to, prvo raspravom o važnosti kulture DBI-ja i njezinom utjecaju na i implikacije za davnu izraelsku kulturu. Drugo, pokazat ćemo korelaciju i divergenciju u svjetonazoru i religiji između drevnog Izraela i okolnih naroda ilustrirajući to s nekoliko specifičnih primjera. Konačno, u trećem dijelu predočit ćemo kako se može postići jasnoća poimanja o teško shvatljivim društvenim tradicijama u nekim biblijskim tekstovima, gledajući ih kroz prizmu pozadine DBI-ja.

\section{Pitanje kulture}

Određena postupanja u hebrejskoj Bibliji, bilo kulturološka, društvena ili vjerska, danas je teško razumjeti ili čak prihvatiti. Premda kao sljedbenici Krista pozvani smo razumjeti i živjeti Božju volju pa ne smijemo zaboraviti da Stari zavjet (SZ) postavlja temelj za učenje i događaje Novog zavjeta (NZ). Biblija je neprestano otkrivenje, a Novi zavjet može se u potpunosti shvatiti samo ako razumijemo podlogu događaja, likove, zakone, žrtveni sustav, savez i obećanja hebrejske Biblije3. Novi zavjet pretpostavlja poznavanje židovske tradicije i religije jednostavno zato što su Isus i njegovi sljedbenici bili Židovi i živjeli su u židovskoj kulturi. Shodno tomu, kako bismo stvarno razumjeli zašto su, primjerice, Židovi iščekivali Mesiju, ili zašto su se židovski duhovne vođe ponašali na određeni način, ili kako

2 "The authors of Scripture operate in a high-context setting. They share a worldview, a history, and a set of experiences with their audience and can assume a lot of common ground. But when we come to the Old Testament as readers, we enter a low-context audience, even as we are trying to interpret a high-context communication. Thus the theological substance of the Old Testament is not just embedded in literature; it is embedded in culture." Slično, danas globalno većina ljudi dijeli isto znanje i iskustva o internetu (Wi-Fi veza), društvenim medijima i pametnim telefonima, nije potrebno objašnjenje (viši kontekst). Ipak, na svijetu postoje mjesta koja su daleko od civilizacije, nemaju struje i tako ne koriste tehnologiju. Takvi ljudi ne dijele globalno znanje o internetu itd. Potrebno im je objašnjenje i podučavanje o tim stvarima kako bi ispravno razumjeli što su internet i društveni mediji, kakav značaj imaju u razvijenom društvu, kakav utjecaj na globalnu kulturu ili što je pametni telefon te kako ga koristiti. Oni jednostavno ne dijele isti kontekst $s$ ostatkom svijeta (niži kontekst).

3 Izraz „hebrejska Biblija“ koristi se u ovom radu naizmjence sa „Stari zavjet“. Oba termina označavaju trideset i devet knjiga koje čine židovski kanon hebrejske Biblije i protestantski kanon Starog zavjeta. 
starozavjetno proročanstvo ima smisla u Novom zavjetu moramo biti upućeni i obrazovani o Starom zavjetu i njegovu svijetu. Korijen kršćanstva leži u hebrejskoj Bibliji, bez koje se uopće ne može ispravno razumjeti cjelokupna biblijska priča. Stoga, naša novozavjetna teologija mora biti upućena odgovarajućom starozavjetnom teologijom. Stari zavjet nam omogućuje da naučimo voljeti i služiti Bogu te otkriva više o Božjem karakteru. Pokazuje kroz opetovana ispunjena proročanstva zašto je Biblija jedinstvena među svetim knjigama - samo ona može potvrditi da je zapravo ono što tvrdi da jest: nadahnuta Božja riječ. Naša je etika također duboko ukorijenjena u Starom zavjetu. Mnogi stavovi, koji se smatraju tipično „kršćanskim“ poput milosti prema strancima i neprijateljima te borba za prava slabih već su utemeljeni u izraelskim tekstovima (npr. Izl 22,20-26; 23,6; 2 Kr 6,22; Izr 25,1-22). Neminovno možemo zaključiti da naša teologija proizlazi iz načina na koji gledamo i shvaćamo Boga, što je nemoguće ako ne poznajemo i doista ne razumijemo njegovu riječ. Stoga će naša revidirana teologija odrediti naše (teološko) djelovanje u svakodnevnom životu.

Problematika je upravo u tome što zapadnjačka kultura i neznanje upućuje naše promišljanje i tumačenje Svetog pisma te neizbježno naš pogled na i poimanje Boga, njegov karakter i njegovu poruku. Isto vrijedi i za suvremenu kulturu; Biblija se različito tumači u zapadnoj kulturi (naglasak na pojedincu) i istočnjačkom načinu razmišljanja (naglasak na zajednicu). Walton $(2006,234)$ objašnjava kako „ne možemo čitati hebrejsku Bibliju kao da je to novinarska ili akademska povijest kakva bi se mogla danas napisati. Takvo bi čitanje ugrozilo namjere, pretpostavke, vrijednosti i poetiku književnosti i njezinih autora". ${ }^{4}$ Ako nam je cilj pojmiti izvornu namjeru autora, moramo razumjeti „okruženje“ u kojem su se dogodili određeni događaji zabilježeni u tekstu. Naime, proučavanjem svijeta Starog zavjeta ispitivanjem drevnih bliskoistočnih tekstova i arheoloških nalaza koji osvjetljavaju svakodnevni život, obiteljske i društvene običaje, vjerske prakse i vjerovanja potpomažemo potragu za točnijim i smislenijim razumijevanjem biblijske poruke koja će unaprijediti način na koji živimo Božji plan na ovom svijetu kao kršćani. Primjera radi, razmotrimo proročanske poruke u hebrejskoj Bibliji proroka „Amosa, Izaije, Jeremije i drugih koje dobivaju na težini i hitnosti $s$ razumijevanjem tadašnjih gorućih pitanja, a to postaje moguće tek onda kad se otkriju priče drugih naroda“"(Hoerth, Mattingly i Yamauchi 1994, predgovor). ${ }^{5}$

4 "We cannot read the Hebrew Bible as if it were journalistic or academic history such as might be written today. Such reading would compromise the intentions, presuppositions, values, and poetics of the literature and its authors."

5 "of Amos, Isaiah, Jeremiah, and others gain in power and urgency as the current affairs of those days are understood, and this only becomes possible as the stories of the other nations are uncovered." 
Glavni alati u ovoj potrazi, prema Waltonu $(2006,18)$, komparativne su studije koje su „grana kulturalnih studija koje pokušavaju izvući podatke iz različitih segmenata šire kulture ( $u$ vremenu i/ili prostoru) u svrhu usporedbe kako bi procijenili ono što se može naučiti od jednog kako bi se poboljšalo razumijevanje drugoga". ${ }^{6}$ Stari zavjet je na mnogim mjestima u skladu sa svojim drevnim kontekstom, ali se radikalno izvlači iz tog konteksta na barem isto toliko mjesta. ${ }^{7}$ To znači da ne možemo usporediti sve tekstove, ali možemo postići objašnjenje kada shvatimo kulturni kontekst i otkrijemo sličnost ili divergenciju (Hess 2014, $7-12)$.

U književnom smislu poznavanje drevnih oblika i žanrova književnosti, kao i istraživanje drevnih jezika, neizmjerno doprinose razumijevanju svetih spisa. ${ }^{8}$ Što se tiče starih jezika, često biblijski tekst koristi različite ili specifične riječi za izražavanje koncepta ili nečeg drugog (npr. nazivi za proroka) (Mead 2014, 263265). U ovakvim slučajevima etimologija određenih riječi ili izraza u drevnim jezicima (poput hebrejskog, akadskog, aramejskog, sirijskog...) može pomoći u shvaćanju onoga što je pojam pokušao prenijeti, a time i često postaju jasnija značenja redaka ili odlomaka iz Svetog pisma. ${ }^{9}$ Vezano uz književne žanrove, retorika varira u pjesmama/molitvama i povijesnoj naraciji. ${ }^{10}$ Recimo, kod istraživanja atributa božanstva na DBI-ju, Walton (2006, 99-100) uočava da se božanstvo

6 "branch of cultural studies in that it attempts to draw data from different segments of the broader culture (in time and/or space) into juxtaposition with one another to assess what might be learned from one to enhance the understanding of another." Postoje mnoge znanstvene metode (tj. razne kritike) koje pomažu u nastojanju da se rekonstruira izvorno značenje i svrha biblijske priče. „Kompetentan egzeget pokušava utvrditi niti više niti manje od onoga što nam tekst može reći, a na ovaj proces ne bi smjele utjecati spekulacije ili kreativno tumačenje“ (Matthews i Moyer 2012, 27).

7 Zapravo, „čak i kad bi se književna ovisnost povremeno mogla odrediti, Stari zavjet jest rekontekstualizirao drevnu književnost s kojom je bio u interakciji“, tvrdi Walton (2017, pogl. 1).

8 „Razumijevanje žanra književnog djela potrebno je ako želimo sagledati autorove namjere. Budući da je percipiranje autorovih namjera bitan sastojak teološke i književne interpretacije teksta, prepoznajemo da razumijevanje žanra doprinosi legitimnom tumačenju“" (Walton 2006, 22).

9 Za takav slučaj, vidi u Greengusu 2014, 91-92.

10 Enciklika Divino Afflante Spiritu (1943.) navodi u članku 40.: „Neka oni koji njeguju biblijske nauke $s$ velikom pažnjom usmjere svoju pozornost na ovu točku i neka ne zanemare nijedno od tih otkrića, bilo u domeni arheologije ili u drevnoj povijesti ili književnosti, koji služe za bolje upoznavanje mentaliteta starih pisaca, kao i njihovog načina i umjetnosti zaključivanja, pripovijedanja i pisanja. S tim u vezi, katolički laici trebali bi uzeti u obzir ne samo da će oni dodatno profanizirati znanost, nego će, štoviše, učiniti uočljivu službu kršćanskoj misiji ako se posvete svom pažnjom i primjenom istraživanja i ispitivanja spomenika iz davnina i daju svoj doprinos, prema svojim sposobnostima, rješavanju dosad nejasnih pitanja“ (The Holy See 1943.). Daljnje informacije o rimokatoličkom gledištu na čitanje Svetog pisma, vidi u enciklikama, Providentissimus Deus (1893.) pape Leona XIII. i Humani Generis (1950.) pape Pija XII. 
različito prikazuje: (1) kao pojedinac (npr. u himnama i mudrosnim spisima); (2) unutar grupe (npr. u mitologiji); i (3) „kada se bog vidi u odnosu na bogove iz drugih skupina (često u kraljevskim natpisima ili sporazumima)“. Stoga, različiti žanrovi nude bogatije razumijevanje načina na koji se božanstvo promatralo i shvaćalo na DBI-ju. Ta spoznaja služi za komparaciju s Božjom slikom u srodnim žanrovima u Starom zavjetu. Isto tako, moramo obratiti pažnju i nastojati shvatiti ono što je zapisano u biblijskim spisima u odnosu na jezik i žanrove koji su se koristili u biblijska vremena i biblijskim zemljama. Zapisi o stvaranju u Postanku 1 i 2 takav su slučaj. Suvremeni čitatelj nastoji shvatiti taj zapis kao moderno znanstveno objašnjenje, a trebao bi u stvari shvatiti to kao pripovijest u kontekstu drevnog svjetonazora.

Nadalje, dvosmisleni, izazovni ili nejasni odlomci u Starom zavjetu mogu se osvijetliti kada zađemo u širu povijesnu pozadinu (Greenwood 2015, pogl. 2). Jedan od načina pribavljanja podataka o životu u biblijskom Izraelu jest ispitivanjem relevantnih arheoloških nalaza. ${ }^{11} \mathrm{Na}$ tom području došlo je do ogromnog razvoja, a stručnjaci su otkrili „detalje o njihovim naseljima, načinu života, strukturama srodstva, domaćem životu, proizvodnji i pripremi hrane, zdravlju i bolesti, odjeći, pjesmi i plesu te materijalima za pisanje“ (King i Stager 2001, xviii). Arheološki stručnjaci i bibličari spajaju sve ove biblijske i izvanbiblijske podatke kako bi prikazali „realistično“ okruženje i život drevnog Izraela, otkrivajući na taj način pojedinosti koje nam pomažu staviti određeni starozavjetni tekst u odgovarajuće povijesno okruženje. Tako kvalitetnije možemo poimati živote ljudi, kako je njihov svijet najvjerojatnije izgledao i što je u to doba bilo važno ili nevažno. Arheološko istraživanje ima nekoliko prednosti kod otkrivanja okružja DBIja. Arheološki fragmenti novih informacija pomažu u oslobađanju našeg uma od suvremenoga zapadnjačkog svjetonazora. Krucijalno je um uroniti u semitski mentalitet jer je hebrejska Biblija postavljena i napisana, kao što je već spomenuto, u drevnoj prošlosti, na stranom jeziku.

U vezi s poviješću Izraela i Jude, arheologija oslobađa teološke tekstove Biblije od zloporabe ili krivog shvaćanja kao primarnih povijesnih izvora, čak i ako jesu i ostaju povijesni izvori svog vremena. Stječemo dvije neovisne, zasebne i komplementarne slike - teologiju i povijest. Također, uz dodatne podatke i mogućnost gledanja fotografija (ili posjete stvarnim mjestima/muzejima) iskopanog materijala ili drevnih lokacija, u konačnici možemo zamisliti vjerodostojniju sliku prošlosti: naselja/kuće, gradove i natpise, razne alate, ukrase i umjetnost. $\mathrm{Na}$

11 Matthews i Moyer $(2012,15-16)$ naglašavaju značaj arheološkog rada i tvrde da „osobito arheologija pojačava naše razumijevanje pisanog teksta fizičkim dokazima... Arheologija je donijela revoluciju u proučavanju teksta Biblije... Arheološki dokazi pružaju neke od najboljih informacija o svakodnevnim životnim uvjetima, arhitekturi, industriji i poljoprivredi, vjerskoj praksi i društvenim običajima u davna vremena“. 
kraju, dobivamo nove podatke i/ili potvrdu povijesnosti biblijskog teksta. ${ }^{12}$ Slijedi nekoliko primjera za ilustraciju. Taylor prizma (šestostrani glinen dokument) nabraja podvige kralja Salmanasera, a među njima se navodi opsada Jeruzalema 701. god. pr. Kr. Drevni „službeni“ spisi ili ljetopisi često su kombinacija činjenica i ideološke propagande (Fant i Reddish 2008, pogl. The Taylor Prism). Ovaj asirski izvještaj o napadu na Judu i Jeruzalem s njihova gledišta znatno potvrđuje biblijsku priču u 2. Kraljevima 18-19, a time i njezinu povijesnost. Stupac 3 Taylor prizme navodi:

Što se tiče Ezekije, Judejca, opsjeo sam četrdeset i šest njegovih utvrđenih gradova opasanih zidinama i okolnih manjih gradova, koji su bili bez broja. Koristeći zbijene rampe i primjenjujući ovnove za udaranje, pješačke napade kroz tunele, proboje i strojeve za opsadu, osvojio sam ih. Izveo sam 200.150 ljudi, mladih i starih, muških i ženskih, konja, mazgi, magaraca, deva, goveda i ovaca, bez broja, i ubrojio ih u plijen. Njega samog, zaključao sam u Jeruzalemu, njegovom kraljevskom gradu, poput ptice u kavezu. Okružio sam ga zemljanim hrpama i učinio mu nezamislivim izlaz na gradska vrata. Njegove gradove koje sam opljačkao odsjekao sam od njegove zemlje i dao ih Mitintiju, kralju Ašdoda, Padiju, kralju Ekrona i Sillibelu, kralju Gaze, i tako sam umanjio njegovu zemlju. Naložio sam mu pristojbe i darove radi svojeg gospodstva nad njim, pored prijašnjeg danka, njihovu godišnju isplatu. Njega, Ezekiju, obuzela je strahovita veličanstvenost moga gospodstva i poslao mi je nakon mog odlaska u Ninivu, moj kraljevski grad, svoje elitne trupe (i) svoje najbolje vojnike, koje je bio doveo kao pojačanje za učvršćivanje Jeruzalema, sa 30 talenata zlata, 800 talenata srebra, odabranim antimonom, velikim blokovima karneola, krevetima s (umetnutom) bjelokosti, slonovim kožama, bjelokosti, drvom ebanovine, drvom šimšira, raznobojnim odjevnim predmetima, odjećom od lana, vunom (obojena) crveno-ljubičastom i plavoljubičastom, posudama od bakra, željeza, bronce i kositra, kolima, opsadnim štitovima, kopljima, oklopima, bodežima za pojas, lukovima i strijelama, bezbroj zamki i oruđa rata, zajedno sa svojim kćerima, ženama iz palače, pjevačima i pjevačicama. On je (također) poslao svoga glasnika da dostavi danak i pokloni se' (Fant i Reddish 2008, pogl. The Taylor Prism). ${ }^{13}$

12 Neki od podataka koje je arheologija priskrbila su: „usjeve koje su uzgajali Izraelci i njihovi susjedi, što su jeli, kako su gradili svoje gradove is kim su trgovali“. Neki od gradova koje nalazimo u Bibliji su iskopani i identificirani, isto vrijedi i za „njihove susjede Filistejce, Feničane, Aramejce, Amonce, Moabite i Edomce. U nekoliko su slučajeva otkriveni natpisi i pečatnjaci koji se mogu izravno povezati s pojedincima spomenutim u biblijskom tekstu" (Finkelstein i Silberman 2001, 5).

13 “'As for Hezekiah, the Judean, I besieged forty-six of his fortified walled cities and surrounding smaller towns, which were without number. Using packed-down ramps and applying battering rams, infantry attacks by mines, breaches, and siege machines, I conquered (them). I took out 200,150 people, young and old, male and female, horses, mules, donkeys, camels, cattle, and sheep, without number, and counted them as spoil. He himself, I locked up within Jerusalem, his royal city, like a bird in a cage. I surrounded him with earthworks, and made it unthinkable for him to exit by the city gate. His cities which I had despoiled I cut off from his land and gave them to Mitinti, king of Ashdod, Padi, king of Ekron, and Silli-bel, king of Gaza, and thus I 
Potvrda za mnoge izraelske i judejske kraljeve spomenute u Starom zavjetu mogu se vidjeti u raznim natpisima DBI-ja. Tako i natpis Meshe, kralja Moaba, navodi da je Omri utemeljitelj izraelske dinastije (usp. $1 \mathrm{Kr}$ 16,20-23; Mih 6,16); "kuća Omri“ ili izvorno Bit-Khumri (Kitchen 2003, 16-17). Osim toga, Kitchen (2003, 18-19) izvještava da je na steli ${ }^{14}$ pronađeno ime judejskog kralja „J(eh) oram II“ i njegova sina „Ahaz Judejski“ (vidi $2 \mathrm{Kr} 8,16$ ). Pronađen je i poznat pečat s tekstom „šeman sluga (= državni ministar) Jeroboam“ koji je pripadao vladavini Jeroboama II., kralja Izraela (vidi $2 \mathrm{Kr}$ 14,23). Kraljevski natpis iz Tel Dana navodi „Davida“ kao vladara južnog kraljevstva i također spominje „Davidovu kuću“. To je prva referenca o Davidu ikad pronađena u drevnoj bliskoistočnoj literaturi (Fant i Reddish 2008, pogl. Tel Dan Inscription). ${ }^{15}$

Dakako, potreban je oprez budući da je arheologija znanost kao i sve ostale znanosti te ima svojih nedostataka. „Arheologija [nije] dokazala da je biblijska pripovijest istinita u svim svojim pojedinostima" (Finkelstein i Silberman 2001, 5). ${ }^{16}$ Prvo, arheološki izvori koje imamo do sada su nepotpuni jer je samo mali postotak DBI-ja iskopan i proučen. Drugo, znanstvena točnost, prema današnjim standardima, nije bila cilj biblijskih autora. Budući da većina arheoloških nalaza i natpisa dopušta različite mogućnosti tumačenja, oni ne daju uvijek krajnju jasnoću; međutim, doprinose stvaranju potpunije slike o Bibliji. Treće, mnogi nalazi uključuju artefakte bez popratnih natpisa; tako je interpretacija artefakata često spekulativna (Steiner 2019, 10).

Područje kulture nipošto nije jedina domena koju valja usporediti s okolnim drevnim društvima, nego i svjetonazor i religija. Naime, rezultati takvih kompariranja nesumnjivo će poboljšati shvaćanje o drevnom Izraelu i Svetom pismu.

diminished his land. I imposed dues and gifts for my lordship upon him, in addition to the former tribute, their yearly payment. He, Hezekiah, was overwhelmed by the awesome splendor of my lordship, and he sent me after my departure to Nineveh, my royal city, his elite troops (and) his best soldiers, which he had brought in as reinforcements to strengthen Jerusalem, with 30 talents of gold, 800 talents of silver, choice antimony, large blocks of carnelian, beds (inlaid) with ivory, elephant hides, ivory, ebony-wood, boxwood, multicolored garments, garments of linen, wool (dyed) red-purple and blue-purple, vessels of copper, iron, bronze and tin, chariots, siege shields, lances, armor, daggers for the belt, bows and arrows, countless trappings and implements of war, together with his daughters, his palace women, his male and female singers. He (also) dispatched his messenger to deliver the tribute and to do obeisance" (Fant and Reddish 2008, chap. The Taylor Prism).

14 Urezana ili klesana površina, obično neka vrsta kamena (ploča, obelisk, stup...).

15 Više podataka o toj temi, vidi u Kitchenu 1997, 22-47; Ortizu 2014, 233-234; i Kitchenu 2003, 92-93.

16 "archaeology has [not] proved the biblical narrative to be true in all of its details." 


\title{
2. Svjetonazor i religija
}

Svjetonazor i religija, posebnosti vjerskih teorija i modus operandi drevnog Izraela mogu se razraditi samo u okvirima drevne bliskoistočne vjerske povijesti. ${ }^{17}$

\begin{abstract}
Naravno, davni Izrael i Juda bili su dio drevnog kulturnog miljea. Iz biblijskog teksta, kao i iz izvanbiblijskih podataka, znamo da je Izrael imao kontakt sa svojim okolnim narodima. Povremeno su živjeli u Egiptu, Babilonu i Perzijskom carstvu. Njihovi su kraljevi sklapali bračne saveze s Fenicijom (1 Kr 16,31) i Egiptom (2 Kr 3). Vodili su bitku s brojnim nacijama i kraljevima. Poželjeli su dobrodošlicu strancima u svoju zajednicu (Lev 19,34; Još 6,22-25; Ruta 4,13-15). Čak su sudjelovali u mnogim istim kultnim običajima kao i njihovi susjedi, poput izgradnje idola (1 Kr 16,25-33), prinošenja dječjih žrtava (2 Kr 16,3) i prakticiranja magije (2 Kr 21,6) (Greenwood 2015, pogl. 2). ${ }^{18}$
\end{abstract}

Nužno je imati na umu da je drevni svjetonazor prilično različit od aktualne zapadno-postmoderne perspektive. Primjerice, drevni ljudi vjerovali su da je apsolutno sve povezano (bogovi, svemir, priroda, ljudi, smrt...), a sve postojanje je konačni rezultat natprirodnog. Dualizam između sakralnog i sekularnog nije postojao. Drevni narodi nisu bili razumski orijentirani, niti su pokušavali objasniti zašto su stvari takve kakve jesu. Religija je bila sustav za služenje bogovima - svrha života; da navedemo samo neke s Waltonova popisa u njegovoj knjizi Drevna bliskoistočna misao i Stari zavjet. ${ }^{19}$ „Bilo bi teško razgovarati sa starima o konceptu božanske intervencije jer je po njihovu svjetonazoru božanstvo bilo previše integrirano u kozmos da bi u njega interveniralo. U većini slučajeva, božanstvo je iznutra, a ne izvana. Sve je iskustvo bilo vjersko iskustvo, sav je zakon bio duhovne prirode, sve dužnosti bile su dužnosti prema bogovima, svi su doga-

17 Pogledajmo, primjerice, Postanak 1,26. Biblijski pisac koristi množinu koja se odnosi na Boga. Tradicionalno se to tumači kao Trojstvo. No mnogi suvremeni bibličari interpretirat će ovaj množinski oblik kao vijeće manjih bića, slično vijećima bogova ili božanskom vijeću DBI-ja. Ovakvo shvaćanje točno bi se uklopilo u mentalni sklop starih i njihovu metafiziku, koja se uvelike razlikuju od suvremene metafizike (Walton 2017, 42). Ostalih pet mogućih tumačenja moglo bi se uklopiti u drevni svjetonazor o božanstvima, a ni jedno od tih drevnih gledišta nije u suprotnosti s kasnije razvijenom teologijom trojedinog Boga (Arnold 2004, 28). Stoga, Moberly $(1999,463)$ s pravom piše da je potrebna samo „umjerena razina povijesnog razumijevanja da bi prepoznali da pisac Postanka 1 nije mogao imati na umu Trojstvo".

18 "Naturally, ancient Israel and Judah were part of this ancient cultural milieu. We know from the biblical text, as well as from extrabiblical data, that Israel had contact with their surrounding nations. They lived at times in Egypt, Babylon and the Persian Empire. Their kings made marriage alliances with Phoenicia (1 Kgs. 16:31) and Egypt (2 Kgs. 3). They engaged in battle with numerous nations and kings. They welcomed foreigners into their community (Lev. 19:34; Josh. 6:22-25; Ruth 4:13-15). They even participated in many of the same cultic practices as their neighbors, such as building idols (1 Kgs. 16:25-33), offering child sacrifices (2 Kgs. 16:3) and practicing sorcery (2 Kgs. 21:6)" (Greenwood 2015, chap. 2). 
đaji imali uzrok u božanstvima. Život je bio religija i religija se nije mogla odijeliti od života" (Walton 2006, pogl. 4). ${ }^{20}$

Uzimajući u obzir drevni bliskoistočni svjetonazor, nije previše iznenađujuće zaključiti da se vjera Hebreja u Boga YHVH kao jedinog Boga sporo razvijala i da u početku nije bila monoteistička. ${ }^{21}$ Walton $(2017,117)$ nas na to podsjeća:

Bog počinje s odnosom, a ne sa zakonom. Ovaj poredak ima savršenog smisla kad prepoznamo da je funkcija zakona pomoći Izraelu da zna kako živjeti u Božjoj prisutnosti. Zakon u ovoj fazi ne bi bio relevantan za Abrama i njegovu obitelj jer Božja prisutnost još nije bila uspostavljena. Slično, Bog ne započinje s doktrinom - skupom vjerovanja na koja se mora pristati da bi došlo do odnosa. Ne traži od Abrama da vjeruje u bilo što osim u Jahvinu pouzdanost da će isporučiti blagodate koje je ponudio. U početku je Abram trebao djelovati (ostaviti ono što je Bog od njega tražio da ostavi), a njegovo je djelovanje zasigurno pokazalo vjeru. No, konkretno, Jahve nije započeo zahtijevanjem lojalnosti ili obožavanjem samo njega. Ne spominje se monoteizam, pa čak ni monolatrija ili henoteizam. ${ }^{22}$ Ne zabranjuje unaprijed likove. Umjesto toga, otkrivamo da je Jahve konstruirao scenarij koji će stvoriti vakuum koji će kasnije popuniti (naglasak dodan). ${ }^{23}$

Narodi oko Izraela štovali su mnoge bogove. Brojni arheološki nalazi poput kipova idola (npr. Baal, Ašera ili likovi bika) u kućama potvrđuju da su drevni

20 "It would be difficult to discuss with ancients the concept of divine intervention because in their worldview deity was too integrated into the cosmos to intervene in it. For the most part, the deity is on the inside, not the outside. All experience was a religious experience, all law was spiritual, all duties were duties to the gods, all events had deity as their cause. Life was religion and religion could not be compartmentalized within life" (Walton 2006, chap. 4).

21 Za detaljniju raspravu i pomalo divergentno gledište na temu „izraelske religije“, vidjeti u Kaufmannu 1961, prvi dio: Karakter izraelske religije, 7-149.

22 Drugi oblik teističkog vjerovanja je henoteizam. „Ovakav način razmišljanja još uvijek ne tvrdi da postoji samo jedan bog, ali inzistira na tome da je samo jedan bog uistinu vrijedan štovanja. Drugi bogovi smatraju se pretendentima na božanstva, varalicama, šarlatanima, nesposobnima ili jednostavno inferiornim bićima nesposobnima za vršenje božanske vlasti. A henoteizam je gledište koje prožima veći dio Starog zavjeta, govoreći o nemoći drugih bogova, zabranjujući njihovo štovanje i proglašava ih prijevarama" (Walton 2017, 31).

23 "God begins with relationship rather than law. This order makes perfect sense once we recognize that the function of the law is to help Israel to know how to live in the presence of God. The law would not be relevant to Abram and his family at this stage because God's presence had not yet been established. Likewise, God does not begin with doctrine-a set of beliefs to which one must agree in order to be in relationship. He does not ask Abram to believe in anything except in Yahweh's trustworthiness to deliver the benefits that he has offered. Initially, Abram needed to act (leave behind what God asked him to leave), and his action surely demonstrated belief. But specifically, Yahweh did not begin by demanding loyalty or worship of him alone. No mention is made about monotheism, or even monolatry or henotheism. No prohibition against images is front-loaded. Instead, we find that Yahweh has constructed a scenario that will create a vacuum that he can later fill" (emphasis added). 
Izraelci u početku također štovali nekoliko bogova (vidi Post $31,19.32 .34$ ). ${ }^{24}$ Kao rezultat toga, u Izraelu su se razvile mnoge značajno različite kultne prakse, dok su neke bile iste $\mathrm{u}$ istom razdoblju. U konačnici, u Izraelu je prevladao monoteizam - oblik religije koji prihvaća postojanje samo jednog Boga i stoga negira postojanje drugih bogova. Možemo utvrditi da je glavna točka razlikovanja između Izraela i okolnih naroda bio savez i Tora. Ne postoji ništa paralelno sa saveznim sporazumom u Izraelu i njihovim susjedima. Za razliku od drugih drevnih bliskoistočnih saveza, samo biblijski božanski savez ima mješavinu svjetovnih i vjerskih pravila (npr. zakon, moralno ponašanje, pravila štovanja i bogoslužja...), a „sve su to bile komponente božanskog saveza koje povezuju Izrael s Bogom, božanskim vladarom“ (Greengus 2012, 108). ${ }^{25}$ Savez je temelj izraelske zajednice. Taj savez (između Boga i cijelog naroda) temelji se na jedinstvenom iskustvu i otkrivenju Boga. Dakle, srž izraelskog promišljanja uvijek je povezana s Deset zapovijedi koje su središte Tore. „Sve obveze koje Jahve ima prema Izraelu ne dolaze zato što služe njegovim potrebama, već zbog saveza. Ljudi služe Jahvi vjerno prema saveznim očekivanjima" (Walton 2006, 140-142). ${ }^{26} \mathrm{YHVH}$ je svom narodu dao savez i novi identitet - svećeničku ulogu, omogućio ljudsko/božanski odnos i jasno razumijevanje njegovih planova i volje. Nasuprot tomu, bogovi DBI-ja tražili su da im ljudi budu „robovi“, služeći svakom njihovu hiru (Kaufmann 1961, 53-54). Unatoč tomu, ljudi nisu bili sigurni je li njihovo službovanje dovoljno da ugode bogovima i napreduju u životu.

Pritom ne čudi što u Bibliji nalazimo i izvještaje koji podsjećaju na magijske rituale (npr. 1 Sam 28,7-20), iako zbunjujuće za suvremenog čitatelja jer magiju povezujemo s trikovima ili suvremenim izmišljenim pričama poput Harryja Pottera. Walton $(2006,264,266)$ objašnjava ovu temu rekavši da se „od početka magija u davnom svijetu ne može odvojiti od kategorije religije... U [nekim] ulogama magija je prepoznata kao općenito korisna za društvo iako bi se mogla zloupotrijebiti u antisocijalne svrhe. Dakle, stručnjak za izvođenje magije bavio se časnom profesijom i trebao se razlikovati od nekromanata ili onih koji bacaju uroke“ ${ }^{27}$ King i Stager $(2001,79)$ potvrđuju istu činjenicu, tvrdeći da je „iscjelje-

24 Razni arheološki nalazi svjedoče također o izraelskom duhovnom preljubu tijekom razdoblja monarhije, vidi u Kitchenu 2003, 214-221.

25 "all these were components of the divine covenant linking Israel with God, the divine sovereign.” Vidi također u Kaufmannu 1961, 233-234. „Savezi obnove nalaze se samo u Bibliji. Organizirao ih je vođa naroda koji je djelovao kao predstavnik Boga, pozivajući ljude da potvrde obveze koje proizlaze iz ranijih božanskih saveza" (Greengus 2012, 118).

26 "Whatever obligations Yahweh has to Israel come not because they serve his needs, but because of the covenant agreement. The people serve Yahweh by faithfulness to the covenant expectations" (Walton 2006, 140-142).

27 "the beginning, magic in the ancient world cannot be dissociated from the category of religion"... In [some] roles magic was recognized as generally beneficial for society, although it 
nje opisano [u 1. Kraljevima 17,21 i 2. Kraljevima 4,18-37] poznato kao 'kontaktna magija, koja se obično prakticirala na drevnom Bliskom istoku“.28

Nadalje, poznajući pozadinu DBI-ja možemo shvatiti zašto je bacanje ždrijeba bilo prihvaćeno u Izraelu. U davna vremena, kada je za određenu situaciju (npr. rat) bilo potrebno neposredno božansko vodstvo, sredstvo je bilo predviđanje/ proricanje (Walton 2006, 142, 256). A u Izraelu su svećenici (ili stanovništvo) koristili Urim i Tumim (vidi Suci 18,5-6; Br 27,21; 1 Sam 28,6). Moguću potvrdu o aktivnoj upotrebi Urima i Tumima od strane izraelskih svećenika možemo pronaći među iskopinama drevnoga grada Tel Dana. „U blizini prostorije s oltarom [u hramu] ležali su drugi kultni predmeti, među njima i velika kocka od plave frite ili majolike" (King i Stager 2001, 329-330). ${ }^{29} \mathrm{Kroz}$ ove primjere, a ima ih još mnogo, postaje očito da je poznavanje šireg konteksta (svijet SZ-a) korisno i od velike pomoći.

Upoznavanje s drevnim okruženjem DBI-ja također može osvijetliti tradiciju, društvenu praksu i ponašanje Izraelaca, koji su modernom umu možda pomalo čudni ili strani, pa tako čini izazovnim interpretaciju Starog zavjeta.

\section{Društveni koncepti i prakse}

Način na koji čitamo i tumačimo određene starozavjetne tekstove može imati pozitivan utjecaj ako se drevni koncepti i prakse ispravno shvaćaju. Većina onoga što čitamo u Svetom pismu, a posebno u hebrejskoj Bibliji, moglo bi nam biti vrlo čudno. Moramo, dakle, temeljito čitati i razumjeti djelovanje i ponašanje koje su opisali ljudi, ali i okolnosti njihovih života u odnosu na društveno okružje Levanta, Mezopotamije i Egipta tog doba. Čak i u biblijskim spisima dolaze razna kulturna ozračja do izražaja. Recimo, kada čitamo o događajima nomadskog naroda, a zatim o životu u faraonskom kraljevstvu Egiptu. Ili, na primjer, kulturno okruženje u izvješću o vremenu kralja Davida i njegova kraljevstva donekle se razlikuje od onoga koje susrećemo kasnije tijekom izgnanstva u Babilonu.

could be abused for antisocial ends. Thus, the specialist in the performance of incantations was engaged in an honorable profession and was to be distinguished from the necromancers or those who cast spells."

28 "healing described [in 1 Kings 17:21 and 2 Kings 4:18-37] is known as 'contactual magic', which was commonly practiced in the ancient Near East."

29 "Near the alter room [in a temple] lay other cultic objects, among them a large die made of blue frit or faience" (King and Stager 2001, 329-330). Frita (staklena) je ostakljeni kompozit najčešće plave (ili zelene) boje, ali nije isto što i fajansa. Pojam „fajansa“ je „izvorno francuski naziv za zemljano posuđe izrađeno u Faenzi u Italiji u 16. stoljeću“ (Dodd i Murfin 1994, 113, 134). Fajansa inače poznatija pod nazivom majolika „keramički je proizvod od pečene gline prevučene neprozirnom kositreno-olovnom caklinom“" (Hrvatska enciklopedija 2021). 
Mnoge drevne društvene konvencije tjeraju nas da se zapitamo zašto je bilo tradicionalno u biblijskom društvu da prvorođenci imaju posebne privilegije (vidi Post 27,19; 49,3; Izl 13,2; $\mathrm{Br} 8,17$ ), da roditelji biraju ženu svom sinu ${ }^{30}$ (npr. Post 21,$21 ; 24,4 ; 38,6)$ ili da muškarac ima više žena - poligamija (npr. David, Salomon). Druge tradicije koje se mogu činiti neobičnim su recimo važnost gostoprimstva i dijeljenja hrane (tj. sveta dužnost ukorijenjena u Lev 19,33-34) i koncept „srodnik-otkupitelj“ (vidi Br 35,19-27; Lev 25,25-33.48-49). Čini se očitim da su Izraelci na svoj način dijelili brojne društvene konvencije s okolnim narodima. A koliko je oblikovanje kulture i utjecaj na kulturu kompleksno, opisuje Walton $(2006,332)$ :

Zajedničko kognitivno okruženje nije posuđeno iz jedne kulture u drugu. Kognitivno okruženje je kulturno naslijeđe oblikovano beskonačnim silama i utječe generaciju po generaciju, kroz složenosti koje se ne mogu pratiti niti identificirati. Čak i danas, kada jedna kultura odluči duboko upiti kognitivno okruženje druge (npr. japansko usvajanje zapadne kulture), rezultat je složena mješavina onoga što se prihvaća u cijelosti, onoga što je prilagođeno, onoga što se uzima na jednoj razini a da se zapravo ne razumije, ono što je potpuno odbačeno, i tako dalje u bezbroj varijacija. ${ }^{31}$

U Postanku 16,1-4, primjerice, saznajemo da je neplodnost Saru potaknula da svom mužu preda ropkinju Hagaru u nadi da će tako imati potomstvo. Nastavak obiteljske loze bio je prioritetni cilj, zbog toga se neplodnost smatrala prokletstvom u Izraelu i okolnim narodima (King i Stager 2001, 48). Shodno tomu, praksa uzimanja „surogat majke“ ili druge žene bila prihvatljiva i smatrala se normalnom, ${ }^{32}$ kako drevni pravni dokument Nuzijev tekst posvojenja svjedoči: „Varijable braka regulirane su ugovorom, uključujući korištenja konkubine za rađanje djece kad je žena bila nerotkinja“ (Walton 2006, 71). Drugi je primjer Tamarina i Judina priča u Postanku 38,6-26 (također Boaz i Ruta), gdje koncept „leviratnog“ braka nalazimo kao temeljnu tradiciju. ${ }^{33}$ King i Stager $(2006,56)$ objašnjavaju da „ako je oženjen muškarac umro bez djece, njegov je brat trebao živjeti zajedno s njegovom udovicom iz nekoliko razloga: kako bi spriječio udovicu da se uda za stranca, kako bi ovjekovječio ime pokojnika i sačuvao u obitelji

30 Za više detalja i ilustracija, vidi u Matthews 2015, pogl. 1 - "Marriage Customs."

31 "The common cognitive environment was not borrowed from one culture to another. A cognitive environment is a cultural heritage shaped by infinite forces and influences generation by generation, through complexities that cannot be traced or identified. Even today when one culture decides to imbibe deeply of the cognitive environment of another (e.g., the Japanese adoption of Western culture), the result is a complex mix of that which is adopted wholesale, that which is adapted, that which is taken at one level without really being understood, that which is utterly rejected, and on and on in innumerable variations."

32 Potražite detaljno objašnjenje u poglavlju Matthews 2015, pogl. 1 - "Importance of an Heir."

33 Više dodatnih informacija, Ibid. 
naslijeđeno zemljište pokojnika“. ${ }^{34} \mathrm{U}$ tom svjetlu Tamarina djela, a ne Judina, bila su po Božjim zapovijedima - da budu plodni i da se množe. Tako je Tamarin zahtjev bio njeno Bogom dano pravo (vidi Post 1,$28 ; 38,25-26$ ).

Podudarnosti se mogu primijetiti i po pitanju ropstva jer su Izraelci posjedovali robove kao i drugi narodi. ${ }^{35}$ No zapažaju se i određene diskrepancije: robovi nisu bili samo vlasništvo već su imali i neka dopuštenja koja su ukazivala na to da se smatraju ljudima (npr. Izl 21,1-11; Pnz 15,12-18); robovi su mogli slaviti vjerske svetkovine sa svojim gospodarima ako su ispunjeni određeni uvjeti; nije ih se smjelo zlostavljati, a služba im je bila ograničena na nekoliko godina (vidi Lev 25). ${ }^{36}$ Osim toga, Izraelci nisu mogli porobiti vlastiti narod. Još jedno neslaganje s okolnim narodima DBI-ja jest to što su žene u Izraelu općenito bile bolje tretirane (osobito udovice). „Kasniji Ponovljeni zakon (koji datira nakon 620. pr. Kr.) također je zahtijevao da se robovi oslobode nakon šest godina službe... i da ih se ne smije poslati praznih ruku (Pnz 15,12-15). Drugim riječima, bivšim robovima dužnicima dat je neki oblik materijalne potpore kako se ne bi odmah vratili u robovanje zbog duga. Ovaj Ponovljeni zakon dodatno je pojednostavio zakon tako što je uključio i muškarce i žene u ovo šestogodišnje, ograničeno razdoblje ropstva (Pnz 15,12)“ (Matthews 2015, pogl. 3). ${ }^{37}$ Štoviše, u Tori su predviđene odredbe za siromašne, slabe i marginalizirane (npr. siročad, udovice, robove, strance; vidi Pnz 10,17-19; 24,17-22; 27,19) (King i Stager 2001, 49, 53). ${ }^{38}$

Naposljetku, određeni neobični ili čak nemoralni postupci u nekim od pripovijesti o patrijarsima mogu se osvijetliti kada se uzme u obzir šira perspektiva

34 "if a married man died without children his brother was to cohabit with his widow for several reasons: to prevent the widow from marrying to an outsider, to perpetuate the name of the deceased, and to preserve within the family the inherited land of the deceased."

35 Iz biblijskog teksta poznato je da je ropstvo bilo dio najranijih početaka povijesti Izraelaca (npr. Abraham je imao najmanje dva poznata roba: Eliezer iz Damaska i Hagaru; Post 15,2; 16,1). U Bibliji je zabilježeno i više robova tijekom monarhijskog razdoblja, osobito rano i u vrijeme rata jer su zatvorenici bili zarobljeni i porobljavani na različite načine: sluge, supruge ili konkubine, građevinski radnici itd.; vidi Pnz 21,10-14; 2 Sam 12,31 (Matthews 2015, pogl. 3).

36 To se odnosi na izraelske sluge i robove. Usporedi Lev 25,39-43 s 25,44-46. Isto vrijedi i za sedmogodišnji otpust u Pnz 15 i Izl 21. Poanta i dalje stoji da su se čak i robovi drugih narodnosti smatrali ljudima s nekim pravima. Primjerice, tako oslobađanje roba, kojega je gospodar trajno ozlijedio, nije ograničeno samo na Hebreje (Izl 21,26-27).

37 "The later Deuteronomic Code (dating to after $620 \mathrm{BCE}$ ) also required that slaves be freed after six years of service... and that they should not be sent away empty-handed (Deut. 15:12-15). In other words, former debt slaves are given some form of economic support so they do not immediately fall back into debt service. This Deuteronomic Code further simplified the law by including both men and women in this six-year, limited period of servitude (Deut. 15:12)" (Matthews 2015, chap. 3).

38 Valja spomenuti da zakoni DBI-ja također propisuju odredbe za neke od ovih skupina. Međutim, u tim zakonima se ne kaže da su pod posebnom zaštitom božanstva kao u Tori. 
okolnih zemalja i njihove kulturno-pravne norme. Takav je slučaj priča o Abramu - Saraji i shemi supruga-sestra (vidi Post 12,10-20):

Ovaj aspekt priče dobro se uklapa u ekološko krhku prirodu drevnog Kanaana, koju je često mučila suša, a zatim i glad. Budući da je Abrahamovo kućanstvo tek nedavno stiglo u Kanaan, bilo bi teško nabaviti hranu od ekonomski napetih lokalnih stanovnika. To jeste značilo daljnji odlazak u Egipat, gdje je tradicionalna mudrost ukazivala da se hrana može kupiti i da se prolaznici toleriraju i povremeno koriste kao privremeni izvori jeftine radne snage. Egipatski tekstovi ipak spominju ,azijate“ ('amu), koji stižu ili kao ratni zarobljenici koji su prodani u egipatsko ropstvo, ili kao izbjeglice koje se na kraju mogu asimilirati u egipatsko društvo ili se vratiti u svoju zemlju (Matthews 2015, pogl. 1). ${ }^{39}$

Matthews (2015, pogl. 1) nudi objašnjenje zašto se Abram vjerojatno koristio obmanom s faraonom:

Još jedna poteškoća s kojom se susreće svaka imigrantska skupina je uklapanje u pravne obrasce grupe domaćina. Imigranti su rijetko upoznati sa zakonima zemlje koju posjećuju i često im se uskraćuje pravna zaštita zajamčena građanima (Post 19,9). To može dovesti do uporabe obmane kao obrambenog mehanizma. Pretpostavljajući da je opstanak grupe imao prioritet nad davanjem svih činjenica potencijalnom neprijatelju, moral takve prijevare nije morao predstavljati veliki problem za pretke. Kao rezultat toga, patrijarhalne naracije sadrže nekoliko priča o prijevarama (naglasak dodan). ${ }^{40}$

Dakako, bilo bi još mnogo toga za napisati o raznim drevnim bliskoistočnim zapisima, arheološkim nalazima i natpisima koji potvrđuju povijesnost Svetog pisma ili dodatno osvjetljuju biblijsku poruku, no za ovaj smo članak odabrali samo neke primjere kako bismo naglasili argument.

39 "This aspect of the story fits well with the ecologically fragile nature of ancient Canaan, which often was plagued with drought and then with famine. Since Abraham's household had only recently arrived in Canaan, it would be difficult to obtain food from the economically stressed local inhabitants. This meant a further trek to Egypt, where traditional wisdom indicated that food could be purchased and that transients were tolerated and occasionally used as temporary sources of cheap labor. Egyptian texts do mention 'Asiatics' ('amu), who arrive either as prisoners of war who are sold into Egyptian slavery, or as refugees who may eventually assimilate into Egyptian society or return to their own lands" (Matthews 2015, chap. 1).

40 "Another difficulty faced by every immigrant group is fitting into the legal patterns of the host group. Immigrants are seldom familiar with the laws of the land, and they are often denied the legal protection guaranteed to citizens (Gen. 19:9). This can lead to the use of deception as a defense mechanism. Assuming that survival of the group took priority over providing a potential enemy with all the facts, the morality of such a deception must not have presented much of a problem for the ancestors. As a result, there are several trickster stories contained in the ancestral narratives" (emphasis added). 


\section{Zaključak}

U lingvistici je opća percepcija da je rečenica sama po sebi dvosmislena, ponekad čak i neshvatljiva. Ako je rečenica dvosmislena ili upitna, potrebno je razumjeti kako je integrirana u opsežniju mrežu značenja (tj. kontekst) kako bi se razumjela i pojasnila namjera teksta. Prilikom dešifriranja drevnih dokumenata shvaćanje konteksta često je teško, posebno u Bibliji. Naše tumačenje stoga je također podložno riziku nesporazuma. Za metodičko vođena znanstvena istraživanja izvorne namjere teksta, tumačenje ovisi o rekonstrukciji „svjetova“ bliskih kultura. Biblijski tekstovi imaju više smisla kada su integrirani u mrežu DBI-ja. Razumijevanje se produbljuje ne samo kada otkrivamo veze i prepoznajemo sličnosti već i kada opažamo razlike. Budući da kontekst mijenja sve, ozbiljno proučavanje Starog zavjeta nije moguće bez uključivanja drevnih bliskoistočnih dokumenata i suvremenih arheoloških nalaza. Svi dodatni podaci pružaju bolji uvid i pomažu u rekonstrukciji drevnog „kognitivnoga okruženja“, što smo u mnogim slučajevima demonstrirali u ovom članku. Tvrdnja svakako stoji da upućena interpretacija stvara kvalitetnije razumijevanje Svetog pisma, što zauzvrat omogućuje kršćanskom vjerniku da učinkovitije provodi svoju poboljšanu teologiju u svakodnevnom životu.

\section{Popis literature}

Arnold, Bill T. 2004. Encountering the Book of Genesis. 2. print. Encountering Biblical Studies. Grand Rapids: Baker Books.

Dodd, Arthur E. i David Murfin, ur. 1994. Dictionary of Ceramics. 3rd ed. London: Inst. of Materials.

Fant, Clyde E. i Mitchell G. Reddish. 2008. Lost Treasures of the Bible: Understanding the Bible through Archaeological Artifacts in World Museums. Grand Rapids: Eerdmans.

Finkelstein, Israel i Neil Asher Silberman. 2001. The Bible Unearthed:

Archaeology's New Vision of Ancient Israel and the Origin of Its Sacred Texts.

New York: Simon \& Schuster Inc.

Greengus, Samuel. 2014. Covenant and Treaty in the Hebrew Bible and in the Ancient Near East. U: Bill T. Arnold I Richard S. Hess, ur. Ancient Israel's History: An Introduction to Issues and Sources, 91-126. Grand Rapids: Baker Academic.

Greenwood, Kyle. 2015. Scripture and Cosmology: Reading the Bible Between the Ancient World and Modern Science. Downers Grove: InterVarsity Press.

Hess, Richard S. 2014. Foundations for a History of Israel. U: Bill T. Arnold i Richard S. Hess, ur. Ancient Israel's History: An Introduction to Issues and Sources, 1-22. Grand Rapids: Baker Academic. 
Hoerth, Alfred J., Gerald L. Mattingly i Edwin M. Yamauchi, ur. 1994. Peoples of the Old Testament. Grand Rapids: Baker Books.

Hrvatska enciklopedija, mrežno izdanje. 2021. majolika. Leksikografski zavod Miroslav Krleža. http://www.enciklopedija.hr/Natuknica.aspx?ID=38202 (pristupljeno 13. 9. 2021.).

Kaufmann, Yehezkel. 1961. The Religion of Israel: From Its Beginnings to the Babylonian Exile. London: George, Allen \& Unwin Ltd.

King, Philip J. i Lawrence E. Stager. 2001. Life in Biblical Israel. 1st ed. Library of Ancient Israel. Louisville: Westminster John Knox Press.

Kitchen, K. A. 2003. On the Reliability of the Old Testament. Grand Rapids: Eerdmans.

Kitchen, Kenneth A. 1997. A Possible Mention of David in the Late Tenth Century BCE, and Deity Dod as Dead as the Dodo? Journal for the Study of the Old Testament 22 (76): 29-44.

Matthews, Victor H. 2015. The Cultural World of the Bible. Grand Rapids: Baker Academic.

Matthews, Victor H. i Don C. Benjamin. 2006. Old Testament Parallels: Laws and Stories from the Ancient Near East. 3rd ed. New York, New Jersey: Paulist Press.

Matthews, Victor H. i James C. Moyer. 2012. The Old Testament: Text and Context. 3rd ed. Grand Rapids: Baker Academic.

Mead, James K. 2014. The Biblical Prophets in Historiography. U: Bill T. Arnold i Richard S. Hess, ur. Ancient Israel's History: An Introduction to Issues and Sources, 262-285. Grand Rapids: Baker Academic.

Moberly, R. W. L. 1999. Theology of the Old Testament. U: David W. Baker i Bill T. Arnold, ur. The Face of Old Testament Studies: A Survey of Contemporary Approaches, 452-478. Grand Rapids: Baker Books.

Ortiz, Steven M. 2014. United Monarchy Archaeology and Literary Sources. U: Bill T. Arnold i Richard S. Hess, ur. Ancient Israel's History: An Introduction to Issues and Sources, 227-261. Grand Rapids: Baker Academic.

Steiner, Margreet L. 2019. Inhabiting the Promised Land: Exploring the Complex Relationship between Archaeology and Ancient Israel as Depicted in the Bible. Oxford; Philadelphia: Oxbow Books.

The Holy See. 1943. Divino Afflante Spiritu. https://www.vatican.va/content/ pius-xii/en/encyclicals/documents/hf_p-xii_enc_30091943_divinoafflante-spiritu.html (pristupljeno 13. 9. 2021.).

Walton, John H. 2006. Ancient Near Eastern Thought and the Old Testament. Grand Rapids: Baker Publishing Group. 


\title{
- - 2017. Old Testament Theology for Christians: From Ancient Context to Enduring Belief. Downers Grove: InterVarsity Press.
}

\author{
Monika Bajić \\ The World of the Bible: \\ Indispensable Context in the Study of the Old Testament
}

\begin{abstract}
The Bible was not originally written for the modern reader, but the testimony of the Church is that it continues to speak God's word to readers/hearers today. However, many modern Bible readers come across texts that need further explanation because the biblical authors did not offer clarification of their writings. They assumed the readers of their time were familiar with the background and could understand the reported events without further explanation. To achieve a "legit" interpretation of Old Testament texts, we first need to understand Scripture correctly, meaning that the biblical text must be read in its narrower and broader context. Only within a context does it become clear what the author meant to say. The main argument of this article is to exhibit that the Bible can only be fully understood against the backdrop of the Ant Near East (ANE). The broader context consists of the knowledge of surrounding nations during Bible times (i.e., Hebrew Bible). By examining ANE texts and archeological findings we achieve a more complete and enriched comprehension of a given scriptural text or passage. This article exhibits through some concrete examples how archeological findings, inscriptions, and Ancient Near East texts can aid in understanding the broader context of the Old Testament world. In return, the wider context of the Bible world can enlighten or clarify a difficult, incomprehensible, or ambiguous biblical text and henceforth scriptural interpretation become more accurate and closer to the original message and meaning.
\end{abstract}

